\title{
Experimental mechanical security assessment used in torsionally flexible Raptor-SK couplings
}

\begin{abstract}
Dodge ${ }^{\circledR}$ Raptor series couplings belong to inseparable, mechanical, and torsionally flexible couplings with the possibility of compensating for the misalignment of axes. In the couplings with the Raptor-SK design, shear pins were additionally applied to protect the drive system from overload. The use of "fuses" in the coupling in the form of shear pins limits the value of the transferred torque to a set (safe) value; beyond which, it is cut off and the drive is consequently disconnected. In this work (with reference to the Raptor-SK coupling), calculations were made to select the diameter of the shear pins depending on the value of the limit torque Mgr. In order to assess the correctness of the selection of pins used in the coupling mechanism, experimental tests were carried out using a testing machine. A comparison was made between the design calculations of the shear pins and the results of research on a test bench.
\end{abstract}

Key words: safety couplings, selection of shear pins, strength tests of pins

\section{INTRODUCTION}

Couplings are used in virtually every machine drive system. In many cases of modern construction, they fulfill not only the role of a shaft connector through which torque is transmitted to the subsequent components of the drive system but also additional functions. These functions can be, for example, compensation of misalignments of the connected shafts' setting (self-adjusting couplings), reduction of dynamic loads (flexible couplings), disconnection of shafts during their operation (controlled, self-acting, centrifugal couplings), transmission of torque in only one direction (one-way coupling), and many others.

Machine drive systems are often exposed to the occurrence of overloads and transient states (e.g., start-ups, blockages). The purpose of protecting its assemblies is to use safety couplings (also called overload couplings). The operation of these couplings is based primarily on two solutions [1]. In the first one, the coupling members are completely disengaged under the influence of the boundary torque value. Then, a properly selected connector (usually in the form of a pin) is destroyed - it is the weakest supporting element in the coupling and, thus, in the whole drive system. The second solution is to use a coupling with a mechanism to limit the value of the transferred torque to a safe value. This group of couplings includes couplings with a friction coupling, for example, where there is a relative slip on the friction linings between the active and passive coupling members during overloading (e.g., SafeSet couplings from Voith [2]).

The considered Raptor-SK coupling with shear pins combines the characteristics of a torsionally flexible coupling and a safety coupling.

The purpose of coupling protection for the machine's drive system components against overloads is most importantly to disconnect the drive at a strictly determined torque value with the highest accuracy of its value preservation. 


\section{DESIGN OF RAPTOR-SK COUPLING}

Dodge ${ }^{\circledR}$ Raptor series couplings belong to nonseparable, mechanical, and torsionally flexible couplings with the possibility of compensating for the misalignment of a shaft (Fig. 1).

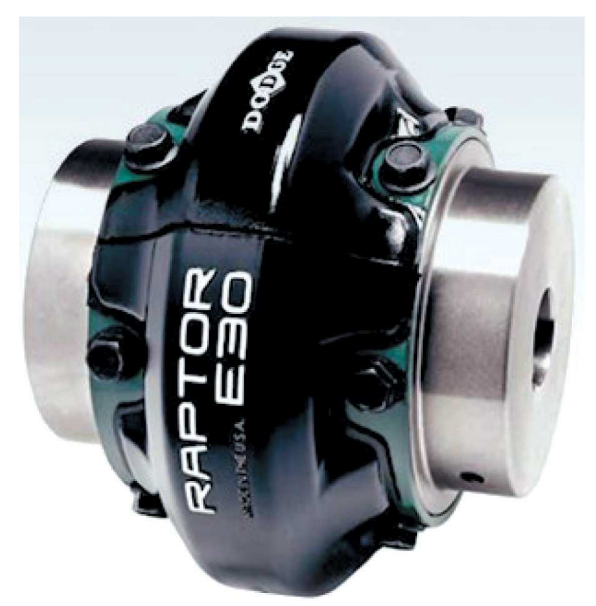

Fig. 1. General view of Dodge ${ }^{\circledR}$ Raptor coupling [3]

The Raptor coupling is characterized above all by the original design of an elastic insert made of natural rubber. According to the manufacturer, applied patented technology called WingLock [4] optimizing the construction of the elastic insert provides high short-term and fatigue strength and long life as compared to other designs of this type of coupling.

Dodge ${ }$ Raptor couplings are produced in many variants; e.g., the coupling may be combined with a disc or a brake drum and is equipped with a torsion angle limiter between the coupling members.

The subject coupling with the designation Raptor SK (Fig. 2) has been equipped with an additional member in which "fuses" in the form of pins (or a pin) subjected to shearing are installed at a given value of transferred torque. This study focuses on the coupling drive overload protection function.

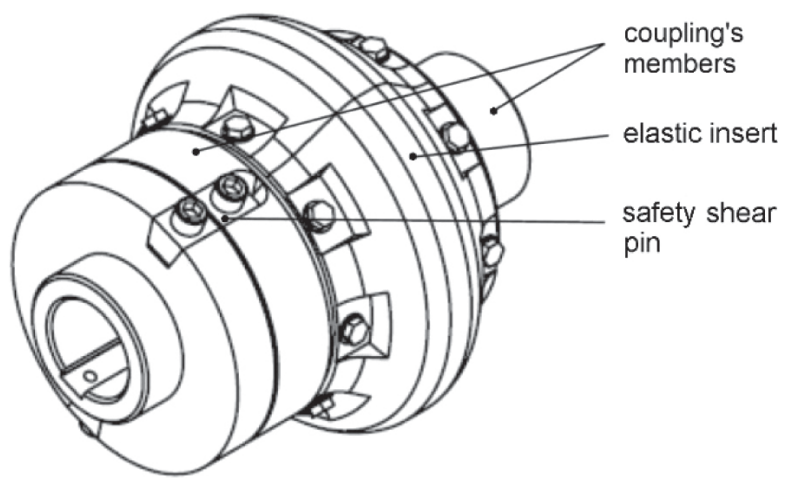

Fig. 2. RAPTOR-SK flexible coupling with safety shear pins

\section{SELECTION OF SAFETY PINS USED IN RAPTOR-SK COUPLING}

When designing a machine drive system, the designer usually selects a coupling from the manufacturer's catalogs; sometimes, it must be specially designed for a given machine [5]. The coupling is selected by calculating the $M_{o}$ torque, taking into account the nominal $M_{n}$ torque that is transmitted by the connected shafts and the overload values specified by factor $k$ :

$$
M_{o}=M_{n} \cdot k
$$

where:

$$
\begin{aligned}
M_{o} & - \text { torque }[\mathrm{Nm}], \\
M_{n} & - \text { nominal torque }[\mathrm{Nm}], \\
k & - \text { overload factor. }
\end{aligned}
$$

In couplings performing the function of the drive system's protection against overload, the values of design boundary moment $M_{g r o}$ causing the pin to be cut (or pins, depending on their number) should additionally be determined. The limit torque at which the coupling members will be disconnected is determined by the coupling manufacturer with the machine drive system designer.

Knowing the values of design limit $M_{\text {gro }}$ for calculating the diameter of pin $d_{o}$, the following formula is applied:

$$
d_{o}=1.6 \sqrt{\frac{M_{g r o}}{D_{p} n R_{t}}}
$$

where:

$$
\begin{aligned}
d_{o}- & \text { diameter of the pin }[\mathrm{m}], \\
D_{p}- & \text { pitch diameter of the pin arrangement (pins) } \\
& {[\mathrm{m}], } \\
n- & \text { number of pin, } \\
R_{t}- & \text { shear strength for the pin material [MPa]. }
\end{aligned}
$$

For the Raptor-SK coupling with the designation/ size of E80 (for which the pitch diameter of the pins is $D_{p}=241 \mathrm{~mm}$ ), calculations have been carried out to select the diameter of the shear pins depending on design limit torque $M_{g r o}$. The calculations were carried out at the design $M_{g r o}$ limit values of 3800, 15,000 and $34,000 \mathrm{Nm}$ for securing pins made of steel for heat treatment and hardening. The calculations were carried out for a coupling with one pin. Table 1 presents the results of the calculations. 
Table 1

Results of calculations for safety pins

\begin{tabular}{|c|c|}
\hline $\begin{array}{c}\text { Calculation value } \\
\text { boundary torque } \\
\boldsymbol{M}_{\text {gro }}[\mathbf{N m}]\end{array}$ & $\begin{array}{c}\text { Computational } \\
\text { diameter of pin } \boldsymbol{d}_{\boldsymbol{o}} \\
{[\mathbf{m m}]}\end{array}$ \\
\hline 3800 & 5 \\
\hline 15,000 & 10 \\
\hline 34,000 & 15 \\
\hline
\end{tabular}

For the assumed values of the $M_{\text {gro }}$ limit torque and the accepted strength data of the steel used, the calculated diameters for the pins are $5 \mathrm{~mm}, 10 \mathrm{~mm}$, and $15 \mathrm{~mm}$, respectively.

After performing strength calculations specifying design diameter $d_{o}$, an experimental verification of the obtained results was made for pins with the above-mentioned diameters.

\section{EXPERIMENTAL TESTS OF PROTECTION PINS USED IN RAPTOR-SK COUPLING}

The use of "fuses" - shear pins - in the coupling limits the value of the transferred torque to a safe value, beyond which the fuses are cut off, consequently, the drive is disconnected. For the purpose of an experimental verification of the structural calculations carried out, shear strength tests were carried out on a test stand (Fig. 3).

The basic element of the test stand is a strength machine (1) on which a specialized shear-clamping device (2) has been installed (Fig. 4). A safety shear pin (3) was secured in the instrument. During the tests using a force transducer (4), the value of force $F$ was measured that is exerted by the testing machine for the device (2) (limit value of this force corresponds to the shear force Ft pin) and by the sensor (5), the value of the working displacement $l$ of the testing machine. Measurement signals are sent to the digital $\mathrm{A} / \mathrm{C}$ measuring module (6), which conditions, measures, and archives both measuring signals with a visualization on a computer screen (7). The $F$ load applied during the tests was static and increased with a fixed speed.

In order to model the process of the "clean" shearing of the pin and its unambiguous fixing and mounting on the station, a specialized original shear-fixing device was designed and made (Fig. 4).
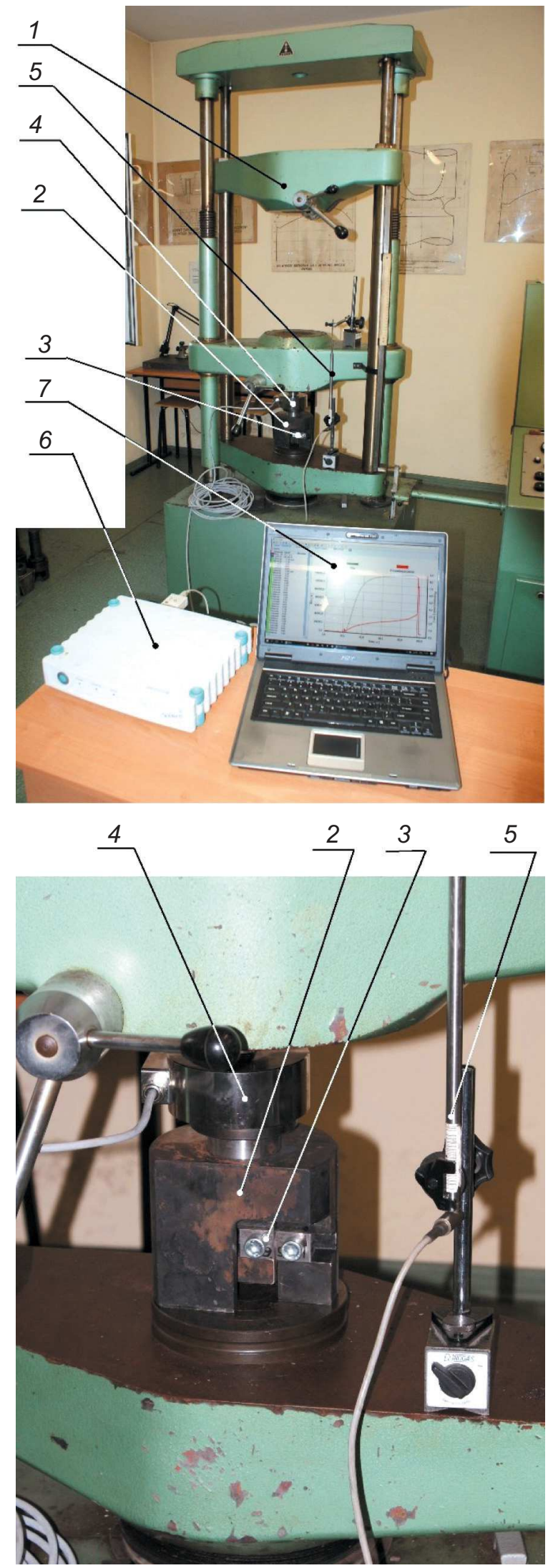

Fig. 3. View of test stand for testing protection pins, where: 1 - strength machine, 2 - fixing and shearing device, 3 - shear bolt, 4 -force transducer, 5 - displacement sensor, 6 - digital A/C measuring module,

$$
7 \text { - computer }
$$


a)

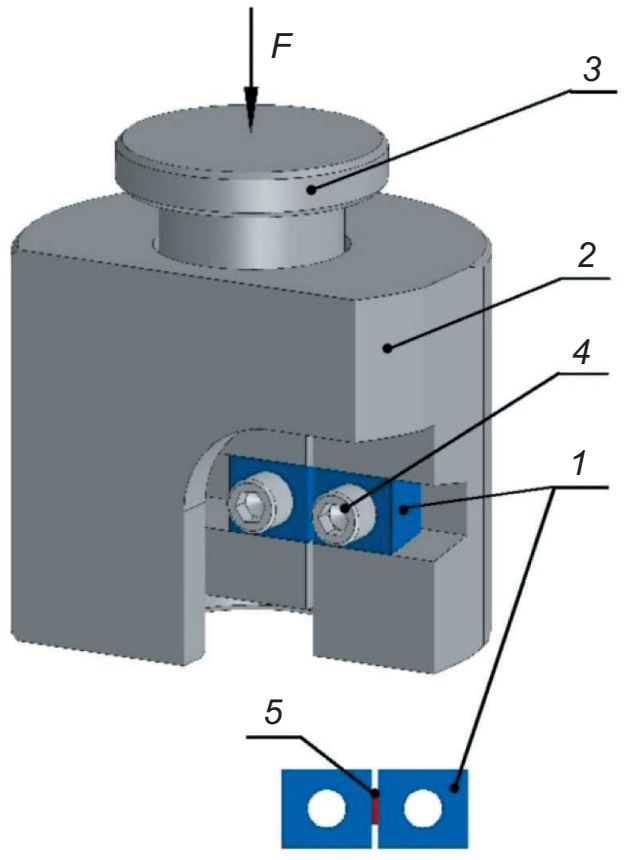

b)

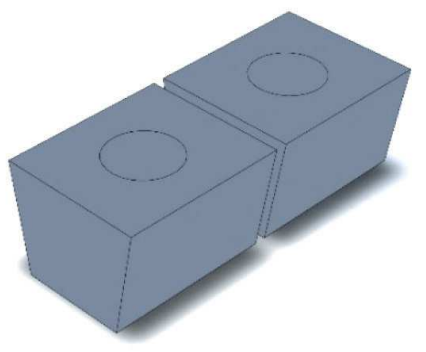

Fig. 4. Shear-cutting device used to shear pins: a) view of device; b) view of shear pin, where: 1 - shear pin, 2 - device base (fixed support), 3 - sliding piston, 4 - fixing screws, 5 - shear part of pin, $F$-force loading device

The device consists of a fixed casing (base) (2) to which one side of the pin (1) and a movable piston (3) are fastened by means of a screw (4) to which the other side of the pin is attached. During the tests, the increasing load $F$ of the piston (3) to limit value $F_{t}$, causes the piston to displace and, consequently, shear the test pin. The course of changes in force value $F$, and displacement 1 is measured and recorded using the measuring equipment.

The tests were carried out for pins with diameter $d$ made of steel for thermal tempering and hardening (Fig. 4) of $5 \mathrm{~mm}, 10 \mathrm{~mm}$, and $15 \mathrm{~mm}$. The pins were hardened throughout. Figure 5a shows the view of the security pin prior to testing, and $5 \mathrm{~b}$ shows it after its cutting.

Table 2 presents the values of shear force $F t$ at which a pin with a given diameter $\mathrm{d}$ was cut as well as the value of corresponding boundary moment $M_{g r}$ for coupling E80. Figure 6 presents an example of the measurement result of the pin measurement with the designation of $\mathrm{p} 7$ using a digital measuring module.
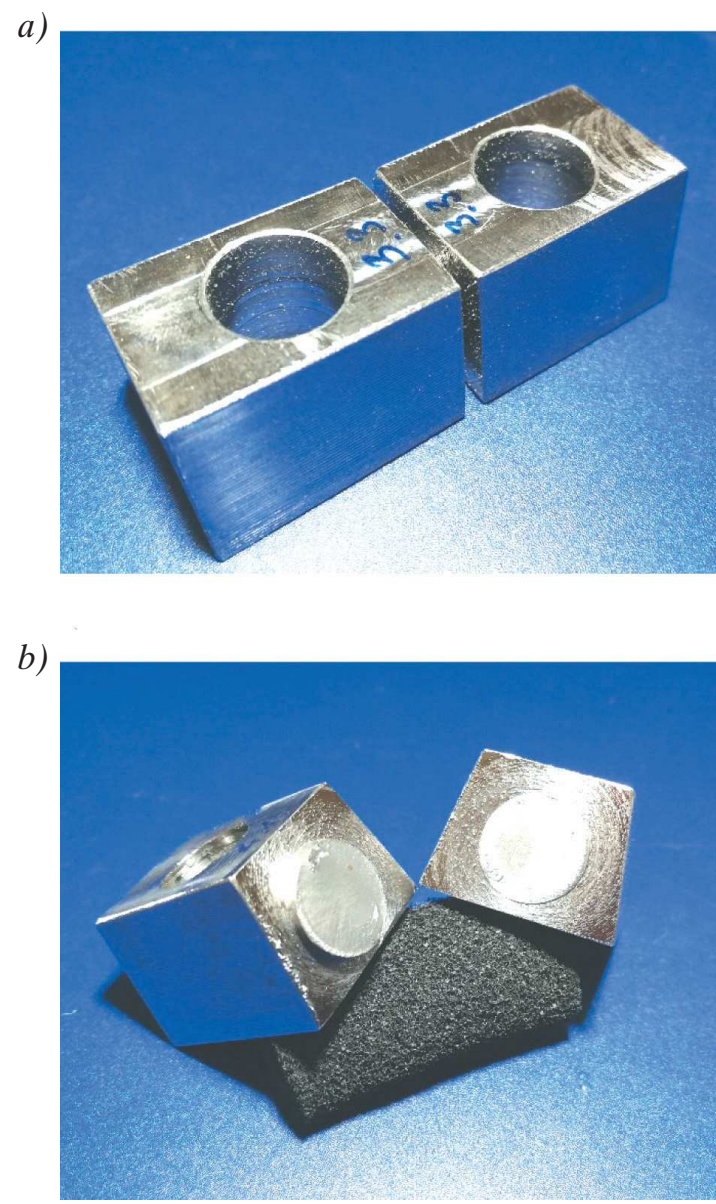

Fig. 5. View of shear pin: a) before test; b) after cutting pin

Table 2

Comparison of results from experimental tests of shearing pins

\begin{tabular}{|c|c|c|c|}
\hline $\begin{array}{c}\text { Pin's } \\
\text { marking }\end{array}$ & $\begin{array}{c}\text { Diameter } \\
\boldsymbol{d}[\mathbf{m m}]\end{array}$ & $\begin{array}{c}\text { Average } \\
\text { value } \\
\text { of shear force } \\
\boldsymbol{F}_{\boldsymbol{t}}[\mathbf{N}]\end{array}$ & $\begin{array}{c}\text { Average value } \\
\text { of boundary } \\
\text { moment } \\
\boldsymbol{M}_{\boldsymbol{g} \boldsymbol{r}} \text { [Nm] }\end{array}$ \\
\hline $\mathrm{p} 1-\mathrm{p} 3$ & 5 & 17,750 & 4277 \\
\hline $\mathrm{p} 4-\mathrm{p} 6$ & 10 & 66,954 & 16,136 \\
\hline $\mathrm{p} 7-\mathrm{p} 9$ & 15 & 147,962 & 35,659 \\
\hline
\end{tabular}

In Figure 7, the values of boundary moment $M_{g r}$ obtained from the conversion of the shear force $F_{t}$ pin and pitch diameter $D_{p}$ (some simplification) are presented in the form of a bar graph. For pins with a diameter of $5 \mathrm{~mm}$, the highest torque $M_{g r \max }$ at which the coupling was disengaged was $4497 \mathrm{Nm}$. On the other hand, the smallest torque value $M_{g r \min }$ was $4008 \mathrm{Nm}$. 


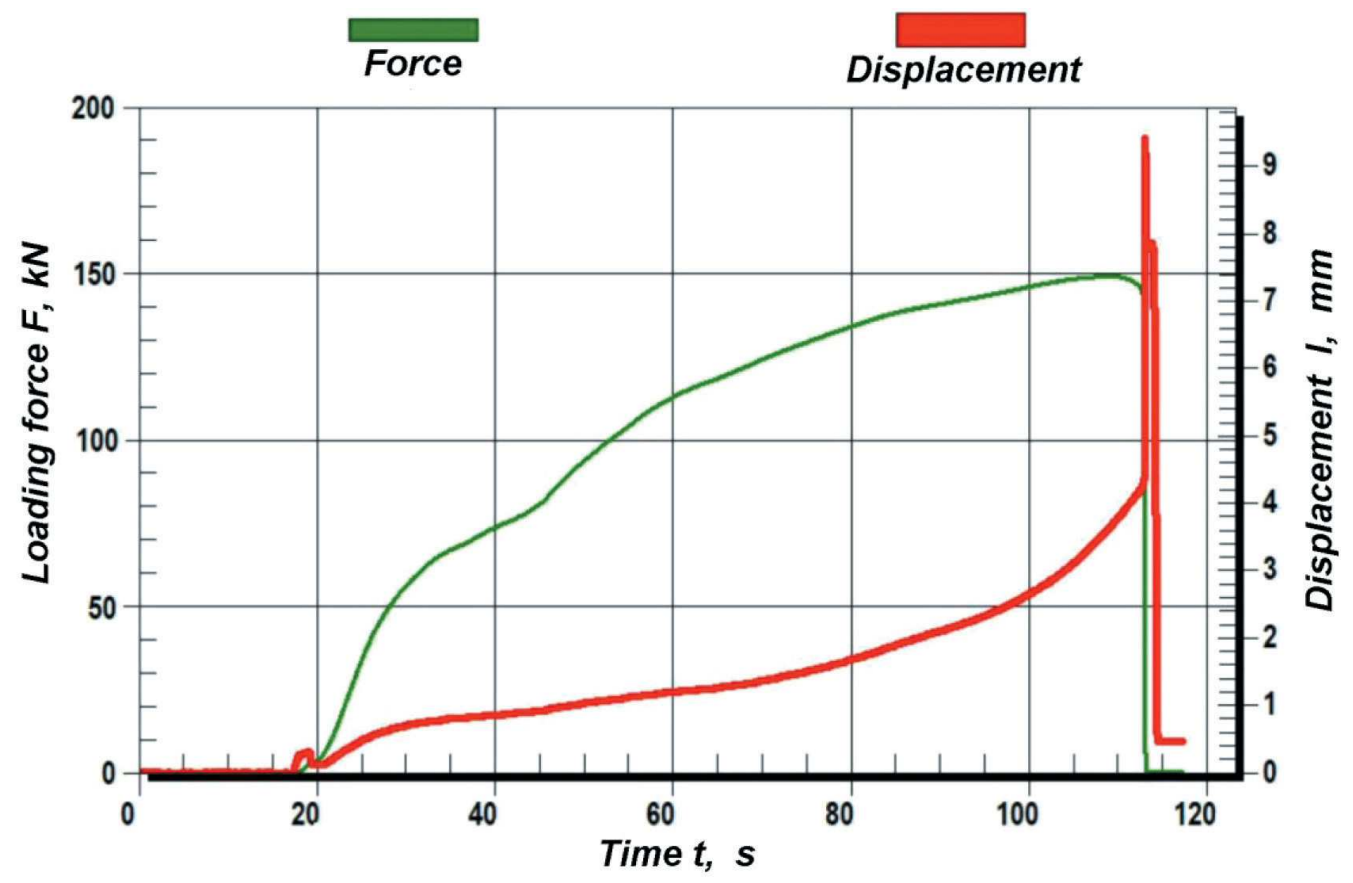

Fig. 6. Example of measurement result measured for $p 7$ pin

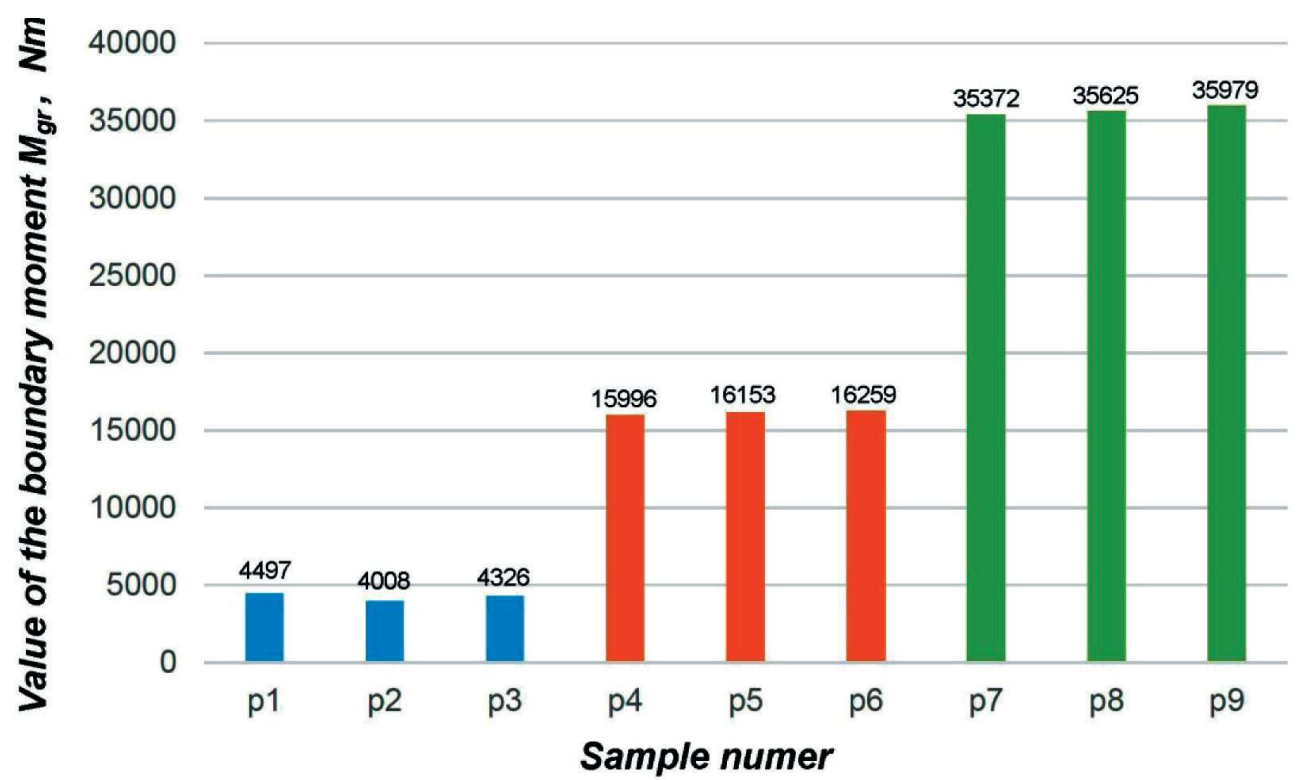

Fig. 7. Limit values for tested shear pins, where $p 1-p 3=$ pins with diameter of $5 \mathrm{~mm}$, p4-p6 = pins with diameter of $10 \mathrm{~mm}$, and $\mathrm{p} 7-\mathrm{p} 9=$ pins with diameter of $15 \mathrm{~mm}$

Therefore, coefficient $\gamma_{5}$, specifying the accuracy of the load limit for the considered coupling is calculated from formula [1].

$$
\gamma_{5}=\frac{M_{g r \max }}{M_{g r \min }}=\frac{4497}{4008}=1.12
$$

Similarly, coefficient $\gamma_{5}$ was determined for the remaining diameters of the protection pins. The calculated values of coefficient $\gamma_{5}$ are shown in Table 3 .
Table 3

Values of $\gamma_{5}$ factor determining accuracy limits of coupling load torque

\begin{tabular}{|l|c|c|c|}
\hline Pin's diameter $\boldsymbol{d}[\mathrm{mm}]$ & 5 & 10 & 15 \\
\hline Value of $\gamma_{5}$ factor & 1.12 & 1.02 & 1.02 \\
\hline
\end{tabular}

For couplings with shear pins in accordance with [1], the value of the coupling disengagement accuracy coefficient should be within a range of 1.1-1.4. 
Therefore, on the basis of the test results, it can be concluded that all of the safety pins have been made correctly, both in terms of the mechanical processing and pins with diameters of $10 \mathrm{~mm}$ and $15 \mathrm{~mm}$ meet the allowance in accordance to [1].

Figure 8 presents a comparison of the calculated values of the $M_{g r o}$ boundary moment with the averaged values of the boundary moment $M_{g r}$ (according to Tab. 2) obtained from the tests.

As it is easy to see, the values of the calculated boundary torque $M_{g r}$ obtained on the basis of the ex- perimental tests (pin cutting) are greater than the values of the $M_{\text {gro }}$ boundary moment obtained from the calculations. For pins with a diameter of $5 \mathrm{~mm}$, the difference was about $12 \%$, for pins with a diameter of $10 \mathrm{~mm}-7 \%$, and for the $15 \mathrm{~mm}$ pins $-5 \%$. The difference in the boundary moment values between the results obtained from the calculations and the results from experimental tests may result, for example, from the value of allowable shear stress $k_{t}$ and the coefficient of proportionality $k_{o}$ in the strength calculations accepted for the calculations.

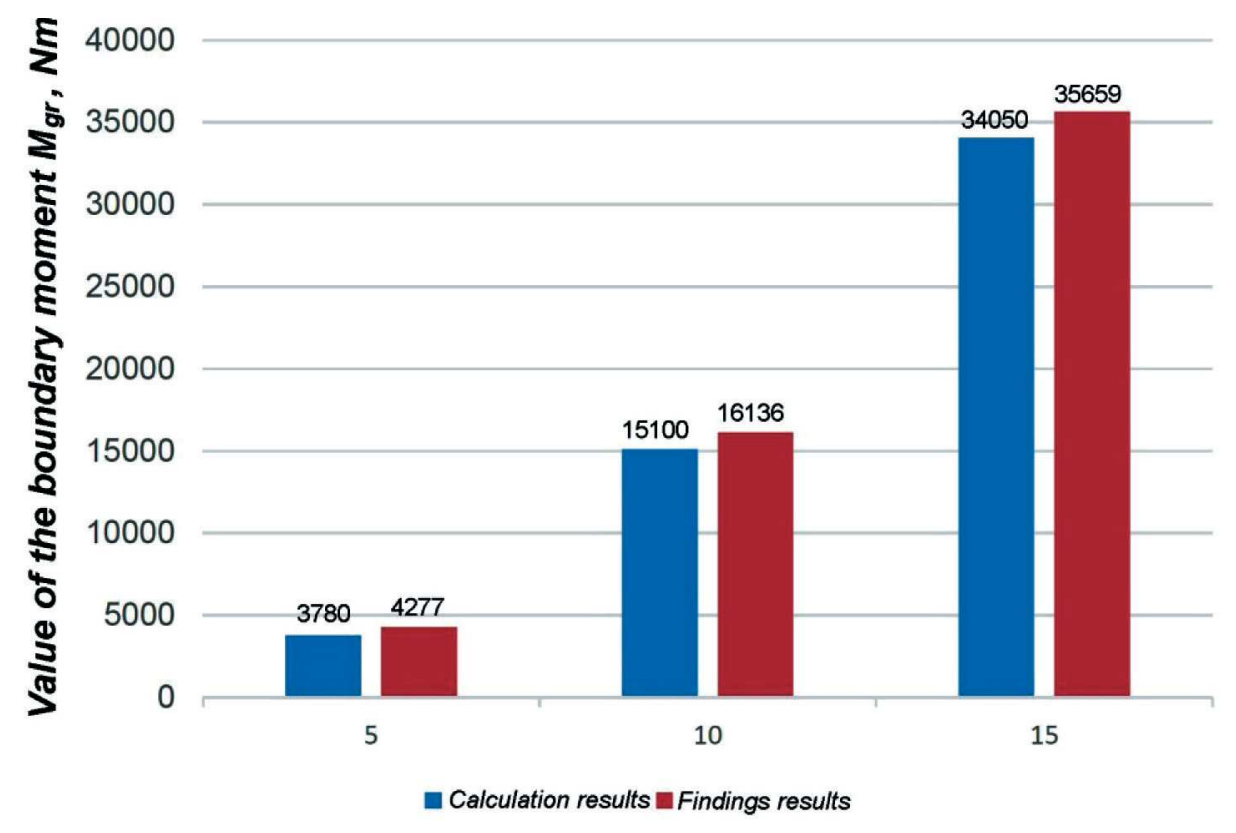

Fig. 8. Comparison of value of calculated boundary moment with average value for tested samples

\section{SUMMARY}

The simplest protection of a drive system's components against overloading are safety couplings with break-away switches. In the case of the Raptor-SK coupling, the connectors have the shape of a cylindrical stud with two mounting surfaces.

The calculations of the diameter of the shear pins for specific values of limit moments performed in the work and experimental tests carried out for their three different diameters showed the following:

- there is a difference in the value of boundary moment $M_{g r}$ between the calculated values $\left(M_{g r o}\right)$ and those obtained from the research $\left(M_{g r}\right)$ (Fig. 8),

- higher values of boundary moment $M_{g r}$ occur for results obtained from the experimental tests (Fig. 8),
- on the basis of the experimental tests, similar values of boundary moment $M_{g r}$ were obtained for each pin diameter (Fig. 7); the indicator determining the accuracy of load limit $\gamma_{5}$ was a maximum of 1.12 for the tested diameter of $5 \mathrm{~mm}$ (Tab. 3).

From the analysis carried out in the work, it can be concluded that, for the calculated shear pin diameters after conducting experimental tests, higher boundary moment values were obtained than assumed in the theoretical calculations. The greater the difference, the smaller the diameter of the locking pin. Ultimately, this will cause the coupling protection to operate at a higher boundary moment than expected (resulting from the calculation). 
Summarizing all of the analyses carried out at work, it can be stated that, the choice of pin diameter cannot be based only on theoretical calculations; the realization of check tests should be considered as well, especially when using these couplings (with safety pins) in machines of high operational importance.

\section{References}

[1] Dietrich M. (red.): Podstawy konstrukcji maszyn, t. 3, Wydawnictwa Naukowo-Techniczne, Warszawa 1999.

[2] https://voith.com/corp-en/torque-limiting-couplings.html [20.05.2018].

[3] www.fena.pl [20.05.2018].

[4] https:/www.baldor.com/brands/baldordodge/products/couplingsclutches-brakes/elastomeric-couplings/raptor [20.05.2018].

[5] Skoć A., Spałek J., Markusik S.: Podstawy konstrukcji maszyn, t. 2, Wydawnictwa Naukowo-Techniczne, Warszawa 2008.
KRZYSZTOF FILIPOWICZ, D.Sc., Eng. MARIUSZ KUCZAJ, Ph.D., Eng.

Department of Mining Mechanization and Robotization

Faculty of Mining and Geology Silesian University of Technology ul. Akademicka 2, 44-100 Gliwice, Poland \{krzysztof.filipowicz, mariusz.kuczaj\}@polsl.pl

PAWEE GRUSZKA, M.Sc., Eng. Fabryka Elementów Napędowych FENA Sp. z o.o. ul. E. Imieli 47, 41-605 Świętochtowice,

Poland

Polanddz.techniczny@fena.pl 


\title{
Doświadczalna ocena zabezpieczeń mechanicznych stosowanych w podatnych skrętnie sprzęgłach Raptor-SK
}

\begin{abstract}
Sprzęgła serii Dodge ${ }^{\circledR}$ Raptor należa do sprzęgiet nierozłacznych, mechanicznych, podatnych skrętnie o możliwości kompensacji odchyłek wspótosiowości. W sprzęłach o oznaczeniu Raptor-SK zastosowano dodatkowo kotki ścinane, zabezpieczajace układ napędowy przed przeciażeniem. Zastosowanie „bezpieczników” w sprzęgle w postaci kotków ścinanych ogranicza wartość przenoszonego momentu obrotowego do wartości ustalonej (bezpiecznej), po której przekroczeniu następuje ich ścięcie, a w konsekwencji roztaczenie napędu. W odniesieniu do sprzegła Raptor-SK przeprowadzono obliczenia mające na celu dobór średnicy kotków ścinanych w zależności od wartości momentu granicznego $M_{g r} W$ celu oceny poprawności doboru kotków użytych $w$ mechanizmie sprzegła przeprowadzono badania doświadczalne z użyciem maszyny wytrzymałościowej. Dokonano porównania wykonanych obliczeń konstruktorskich kotków ścinanych z wynikami badań na stanowisku badawczym.
\end{abstract}

Słowa kluczowe: sprzęło bezpieczeństwa, dobór kołków ścinanych, badania wytrzymatościowe kotków

\section{WPROWADZENIE}

Sprzęgła mają zastosowanie praktycznie w każdym układzie napędowym maszyny. W wielu przypadkach nowoczesnych konstrukcji spełniają one funkcję nie tylko łącznika wałów, przez który przekazywany jest moment obrotowy na kolejne podzespoły układu napędowego, lecz muszą one również spełniać funkcje dodatkowe. Tymi funkcjami mogą być na przykład redukcja mimośrodowości ustawienia łączonych wałów (sprzęgła samonastawne), złagodzenie obciążeń dynamicznych (sprzęgła podatne), rozłączanie wałów podczas ich pracy (sprzęgła sterowane, samoczynne, odśrodkowe), przenoszenie momentu obrotowego tylko w jednym kierunku (sprzęgło jednokierunkowe) i wiele innych.

Układy napędowe maszyn narażone są często na wystąpienie przeciążeń i stanów pracy nieustalonej (np. rozruchów, zablokowań). W celu ochrony jego zespołów stosuje się sprzęgła bezpieczeństwa nazywane również przeciążeniowymi. Działanie tych sprzęgieł opiera się przede wszystkim na dwóch rozwiąza- niach [1]. W pierwszym dochodzi do całkowitego rozłączenia członów sprzęgła pod wpływem granicznej, założonej wartości momentu obrotowego. Ulega wtedy zniszczeniu odpowiednio dobrany łącznik (najczęściej w postaci kołka), który jest najsłabszym elementem nośnym w sprzęgle, a tym samym w całym układzie napędowym. Drugim rozwiązaniem jest zastosowanie sprzęgła $\mathrm{z}$ mechanizmem ograniczenia wartości przenoszonego momentu do wartości bezpiecznej. Do tej grupy sprzęgieł należą np. sprzęgła z łącznikiem ciernym, gdzie podczas przeciążenia dochodzi do względnego poślizgu na wykładzinach ciernych pomiędzy członem czynnym i biernym sprzęgła (np. sprzegła SafeSet firmy Voith [2]).

Rozpatrywane sprzęło Raptor-SK ze ścinanymi kołkami łączy w sobie cechy sprzęgła podatnego skrętnie oraz sprzęgła bezpieczeństwa.

W ochronie przez sprzęgło elementów układu napędowego maszyny przed przeciążeniami najbardziej istotne jest, aby rozłączanie napędu odbyło się przy ściśle określonej wartości momentu obrotowego z możliwie dużą dokładnością jej zachowania. 


\section{BUDOWA SPRZEG KA RAPTOR-SK}

Sprzęgła serii Dodge®Raptor należą do sprzęgieł nierozłącznych, mechanicznych, podatnych skrętnie o możliwości kompensacji odchyłek współosiowości (rys. 1).

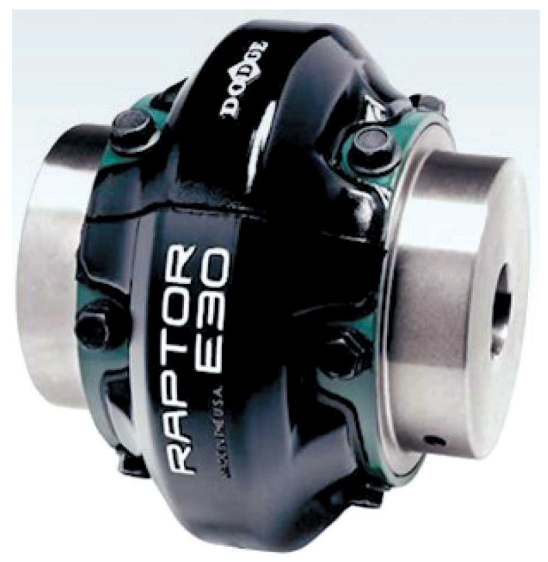

Rys. 1. Widok ogólny sprzegła serii Dodge®Raptor [3]

Sprzęgło Raptor charakteryzuje się przede wszystkim oryginalną konstrukcją wkładki elastycznej wykonanej z kauczuku naturalnego. Zastosowana opatentowana technologia o nazwie WingLock [4] optymalizująca konstrukcje wkładki elastycznej, według producenta, zapewnia dużą wytrzymałość doraźną i zmęczeniową oraz długą żywotność w porównaniu z innymi konstrukcjami tego typu sprzęgieł.

Sprzęgła Dodge ${ }^{\circledR}$ Raptor produkowane są w wielu wariantach, np. sprzęgło może być zespolone z tarczą lub z bębnem hamulcowym, wyposażone w ogranicznik kąta skręcenia pomiędzy członami sprzęgła.

Przedmiotowe sprzęgło o oznaczeniu Raptor-SK (rys. 2) zostało wyposażone w dodatkowy człon, w którym montowane są „bezpieczniki” w postaci kołków (lub kołka) podlegających ścinaniu przy określonej wartości przenoszonego momentu obrotowego. W niniejszym opracowaniu skupiono się na realizowanej przez sprzęgło funkcji zabezpieczenia układu napędowego przed przeciążeniem.

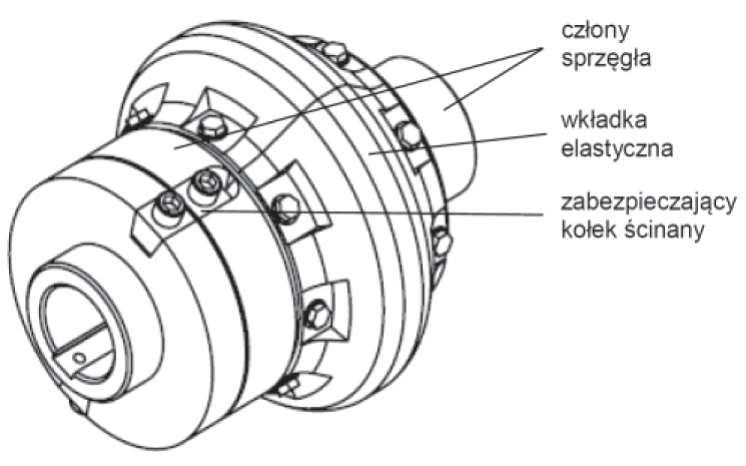

Rys. 2. Sprzęto podatne RAPTOR-SK z zabezpieczającymi kotkami ścinanymi

\section{DOBÓR KOŁKÓW ZABEZPIECZAJĄCYCH ZASTOSOWANYCH W SPRZĘGLE RAPTOR-SK}

Projektując układ napędowy maszyny, konstruktor najczęściej dobiera sprzęgło z katalogów producentów, czasem musi ono być specjalnie zaprojektowane dla danej maszyny [5]. Sprzęgło dobiera się, obliczając moment obrotowy $M_{o} \mathrm{z}$ uwzględnieniem momentu nominalnego $M_{n}$, jaki przenoszony jest przez łączone wały oraz wartości przeciążenia określonego współczynnikiem $k$ :

$$
M_{o}=M_{n} \cdot k
$$

gdzie:

$M_{o}$ - moment obrotowy [Nm],

$M_{n}$ - moment nominalny [Nm],

$k$ - współczynnik przeciążenia.

W sprzęgłach pełniących funkcję zabezpieczenia układu napędowego przed przeciążeniem dodatkowo należy wyznaczyć wartości obliczeniowego momentu granicznego $M_{\text {gro }}$ powodującego ścięcie kołka (lub kołków w zależności od ich liczby). Moment graniczny, przy którym ma nastąpić rozłączenie członów sprzęgła, ustala producent sprzęgła z projektantem układu napędowego maszyny.

Znając wartości obliczeniowego momentu granicznego $M_{g r o}$, do obliczenia średnicy kołka $d_{o}$ stosuje się wzór:

$$
d_{o}=1,6 \sqrt{\frac{M_{g r o}}{D_{p} n R_{t}}}
$$

gdzie:

$$
\begin{aligned}
d_{o}- & \text { średnica kołka }[\mathrm{m}], \\
D_{p}- & \text { średnica podziałowa rozmieszczenia kołka } \\
& \text { (kołków) }[\mathrm{m}], \\
n- & \text { liczba kołków, } \\
R_{t}- & \text { wytrzymałość na ścinanie dla materiału koł- } \\
& \text { ka [MPa]. }
\end{aligned}
$$

Dla sprzęgła Raptor-SK o oznaczeniu/rozmiarze E80, dla którego średnica podziałowa rozmieszczenia kołków wynosi $D_{p}=241 \mathrm{~mm}$, przeprowadzono obliczenia mające na celu dobór średnicy kołka ścinanego w zależności od wartości obliczeniowego momentu granicznego $M_{g r o}$. Obliczenia przeprowadzono przy obliczeniowych momentach granicznych $M_{\text {gro }}$ wynoszących 3800, 15000 oraz 34000 Nm dla kołków zabezpieczających wykonanych ze stali do ulepszania cieplnego i hartowania po obróbce cieplnej o wytrzymałości na ścinanie $R_{t}=800 \mathrm{MPa}$. Przedmiotowe obliczenia zostały przeprowadzone dla sprzęgła z jednym kołkiem. W tabeli 1 przedstawiono wyniki obliczeń. 
Tabela 1

Wyniki obliczeń kołków zabezpieczających

\begin{tabular}{|c|c|}
\hline $\begin{array}{c}\text { Wartość obliczeniowego } \\
\text { momentu granicznego } \\
\boldsymbol{M}_{\text {gro }}[\mathbf{N m}]\end{array}$ & $\begin{array}{c}\text { Średnica obliczeniowa } \\
\text { kołka } \boldsymbol{d}_{\boldsymbol{o}}[\mathbf{m m}]\end{array}$ \\
\hline 3800 & 5 \\
\hline 15000 & 10 \\
\hline 34000 & 15 \\
\hline
\end{tabular}

Dla założonych wartości momentu granicznego $M_{\text {gro }}$ i przyjętych danych wytrzymałościowych zastosowanej stali, obliczone średnice do kołków wynoszą odpowiednio: $5 \mathrm{~mm}, 10 \mathrm{~mm}$ oraz $15 \mathrm{~mm}$.

Po wykonaniu obliczeń wytrzymałościowych określających średnicę obliczeniową $d_{o}$ przeprowadzono doświadczalną weryfikację uzyskanych wyników dla kołków o ww. średnicach.

\section{BADANIA DOŚWIADCZALNE KOŁKÓW ZABEZPIECZAJĄCYCH ZASTOSOWANYCH W SPRZECLEE RAPTOR-SK}

Zastosowanie „bezpieczników” - kołków ścinanych w sprzęgle ogranicza wartość przenoszonego momentu obrotowego do wartości bezpiecznej, po której przekroczeniu następuje ich ścięcie, a w konsekwencji rozłączenie napędu. W celu doświadczalnej weryfikacji przeprowadzonych obliczeń konstrukcyjnych wykonano badania wytrzymałości kołków na ścinanie na stanowisku badawczym (rys. 3).

Bazowym elementem stanowiska badawczego jest maszyna wytrzymałościowa (1), na której zamocowany został specjalizowany przyrząd ustalająco-ścinający (2) (rys. 4). W przyrządzie mocowano zabezpieczający kołek ścinany (3). Podczas badań za pomocą czujnika siły (4) mierzona była wartość siły $F$, którą wywiera maszyna wytrzymałościowa na przyrząd (2) (wartość graniczna tej siły odpowiada sile ścinającej $F_{t}$ kołek) oraz za pomocą czujnika (5), wartość przemieszczenia roboczego $l$ maszyny wytrzymałościowej. Sygnały pomiarowe przesyłane są do cyfrowego modułu pomiarowego A/C (6), który kondycjonuje, mierzy $i$ archiwizuje oba sygnały pomiarowe $z$ wizualizacją na ekranie komputera (7). Zadawane podczas badań obciążenie $F$ miało charakter statyczny i zwiększane było ze stałą, ustaloną sprzętowo prędkością.

W celu zamodelowania procesu „czystego” ścinania kołka oraz jego jednoznacznego ustalenia i mocowania na stanowisku zaprojektowano i wykonano specjalizowany, oryginalny przyrząd ustalająco-ścinający (rys. 4).
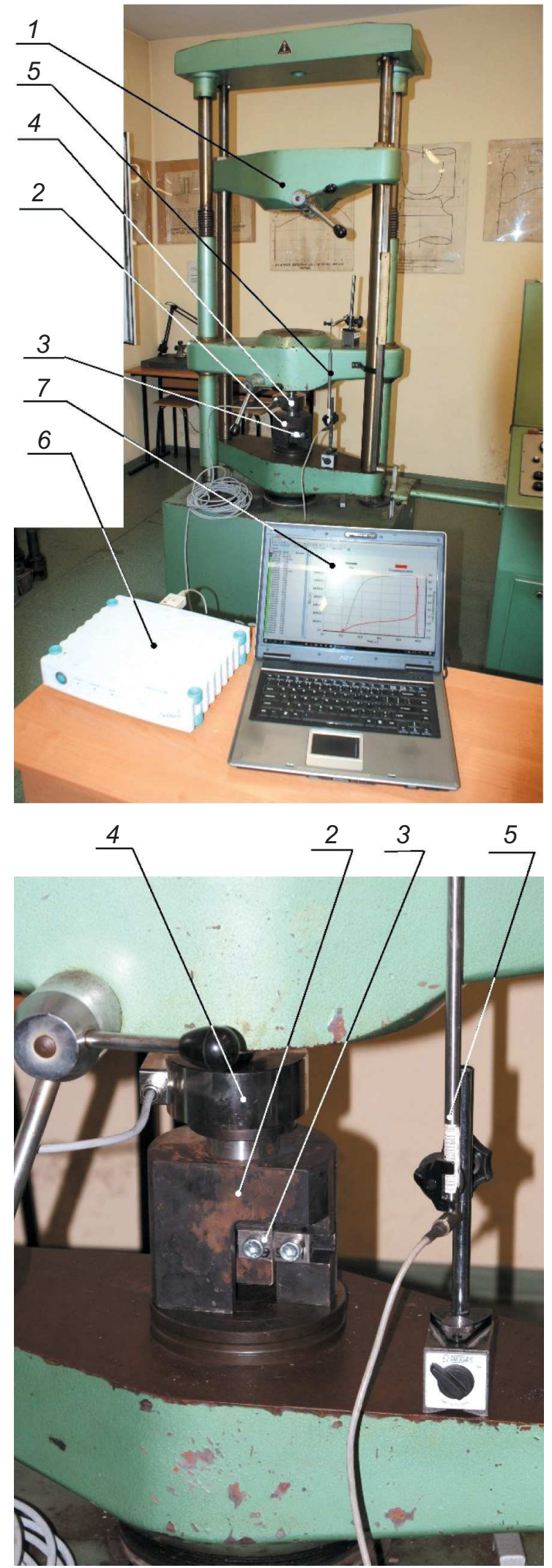

Rys. 3. Widok stanowiska badawczego do badania kotków zabezpieczających, gdzie: 1 - maszyna wytrzymatościowa, 2 - przyrząd ustalająco-ścinający, 3 - kotek zabezpieczajacy ścinany, 4 - czujnik sity, 5 - czujnik przemieszczenia, 6 - cyfrowy modut pomiarowy $A / C$, 7 - komputer 
a)

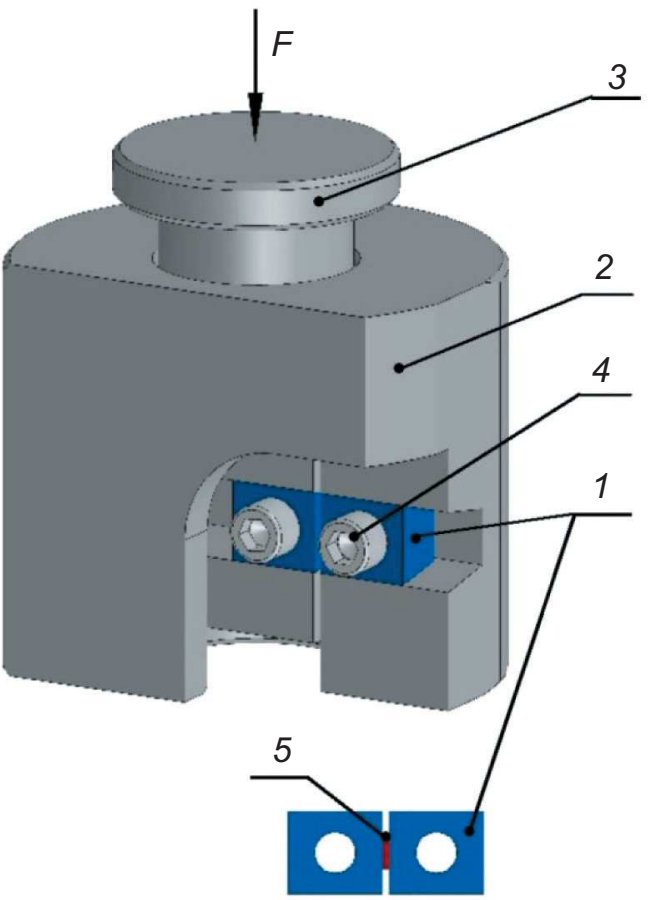

b)

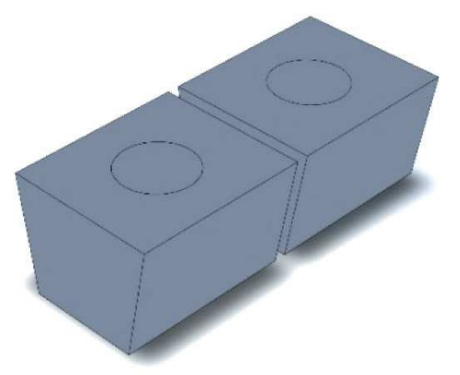

Rys. 4. Przyrząd ustalająco-ścinający wykorzystany do ścinania kołków zabezpieczających: a) widok przyrza$d u$; b) widok ścinanego kotka zabezpieczającego, gdzie: 1 - kołek ścinany, 2 - podstawa przyrzadu (nieruchoma obudowa), 3 - ttok przesuwny, 4 - śruby mocujace, 5 - część ścinana kotka, F - sita obciażajaca przyrzad

Przyrząd składa się z nieruchomej obudowy (podstawy) (2), do której śrubą (4), mocowany jest jedną stroną kołek (1) oraz przesuwanego tłoka (3), do którego mocuje się drugą stronę kołka. Podczas badań zwiększające się obciążenie $F$ tłoka (3) do wartości granicznej $F_{t}$, powoduje przesuw tłoka, a w konsekwencji ścięcie badanego kołka. Przebieg zmian wartości siły $F$ i przesunięcia $l$ jest mierzony i rejestrowany za pomocą aparatury pomiarowej.

Badania przeprowadzono dla kołków wykonanych ze stali do ulepszania cieplnego i hartowania (rys. 4), o średnicy $d$ wynoszącej $5 \mathrm{~mm}, 10 \mathrm{~mm}$ oraz $15 \mathrm{~mm}$. Kołki były hartowane na wskroś. Na rysunku 5a przedstawiono widok kołka zabezpieczającego przed wykonaniem badania, a na rysunku $5 \mathrm{~b}$ - po jego ścięciu. a)

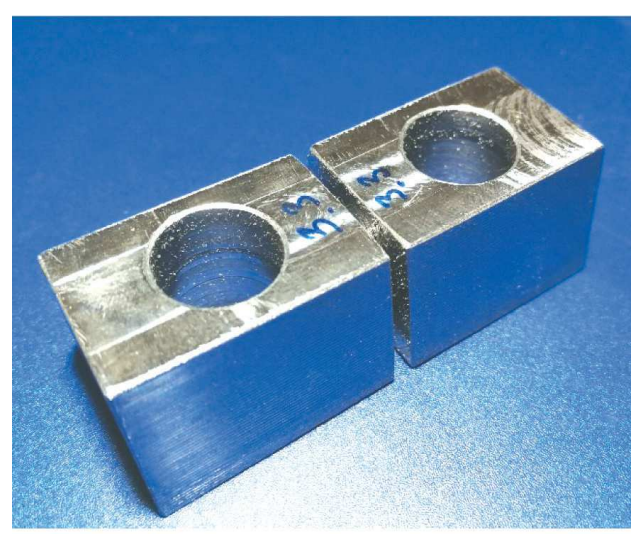

b)

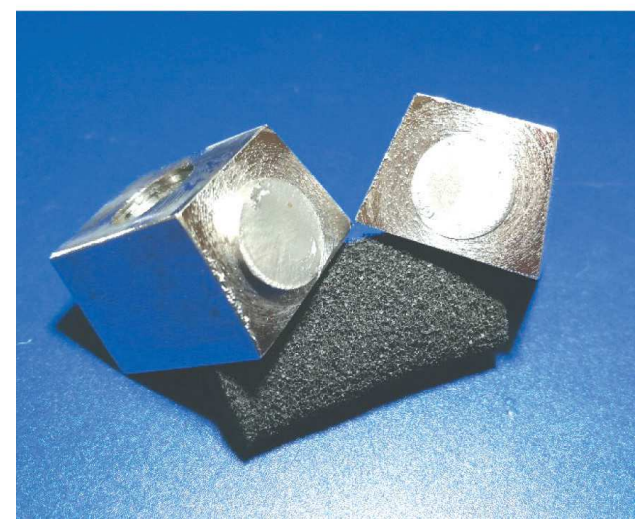

Rys. 5. Widok ścinanego kotka zabezpieczającego:

a) przed wykonaniem badania; b) po ścięciu kotka

W tabeli 2 przedstawiono wartości siły ścinającej $F_{t}$, przy której kołek o określonej średnicy $d$ ulegał ścięciu, oraz wartość odpowiadającego jej momentu granicznego $M_{g r}$ dla sprzęgła E80. Na rysunku 6 przedstawiono przykładowy wynik rejestracji pomiaru kołka o oznaczeniu p7, za pomocą cyfrowego modułu pomiarowego.

Tabela 2

\section{Zestawienie wyników z badań doświadczalnych ścinania kołków zabezpieczających}

\begin{tabular}{|c|c|c|c|}
\hline $\begin{array}{c}\text { Oznaczenie } \\
\text { kołka }\end{array}$ & $\begin{array}{c}\text { Średnica } \\
\boldsymbol{d} \text { [mm] }\end{array}$ & $\begin{array}{c}\text { Wartość } \\
\text { średnia } \\
\text { sily } \\
\text { ścinającej } \\
\boldsymbol{F}_{\boldsymbol{t}}[\mathbf{N}]\end{array}$ & $\begin{array}{c}\text { Wartośćśrednia } \\
\text { momentu } \\
\text { granicznego } \\
\boldsymbol{M}_{\boldsymbol{g r}}[\mathbf{N m}]\end{array}$ \\
\hline $\mathrm{p} 1-\mathrm{p} 3$ & 5 & 17750 & 4277 \\
\hline $\mathrm{p} 4-\mathrm{p} 6$ & 10 & 66954 & 16136 \\
\hline $\mathrm{p} 7-\mathrm{p} 9$ & 15 & 147962 & 35659 \\
\hline
\end{tabular}

$\mathrm{Na}$ rysunku 7 przedstawiono w postaci wykresu słupkowego wartości momentu granicznego $M_{g r}$ uzyskane z przeliczenia siły ścinającej $F_{t}$ kołek oraz średnicy podziałowej $D_{p}$ (pewne uproszczenie). 


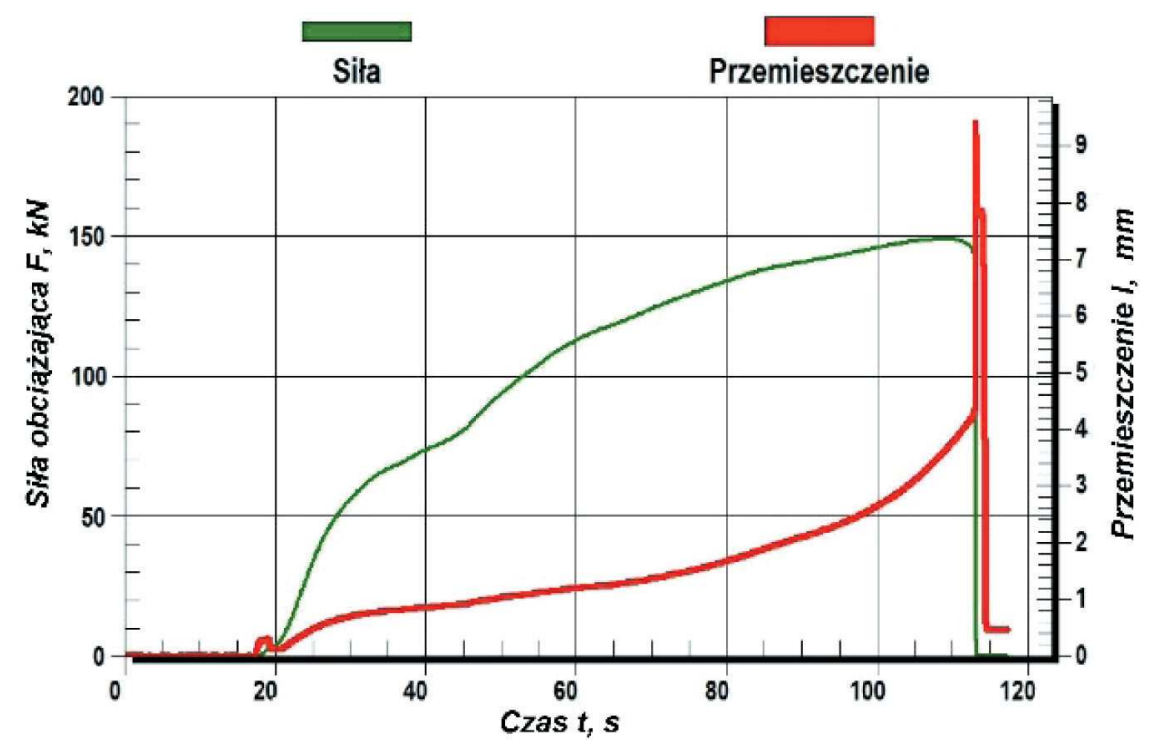

Rys. 6. Przykładowy wynik pomiaru wielkości mierzonych dla kotka o oznaczeniu p7

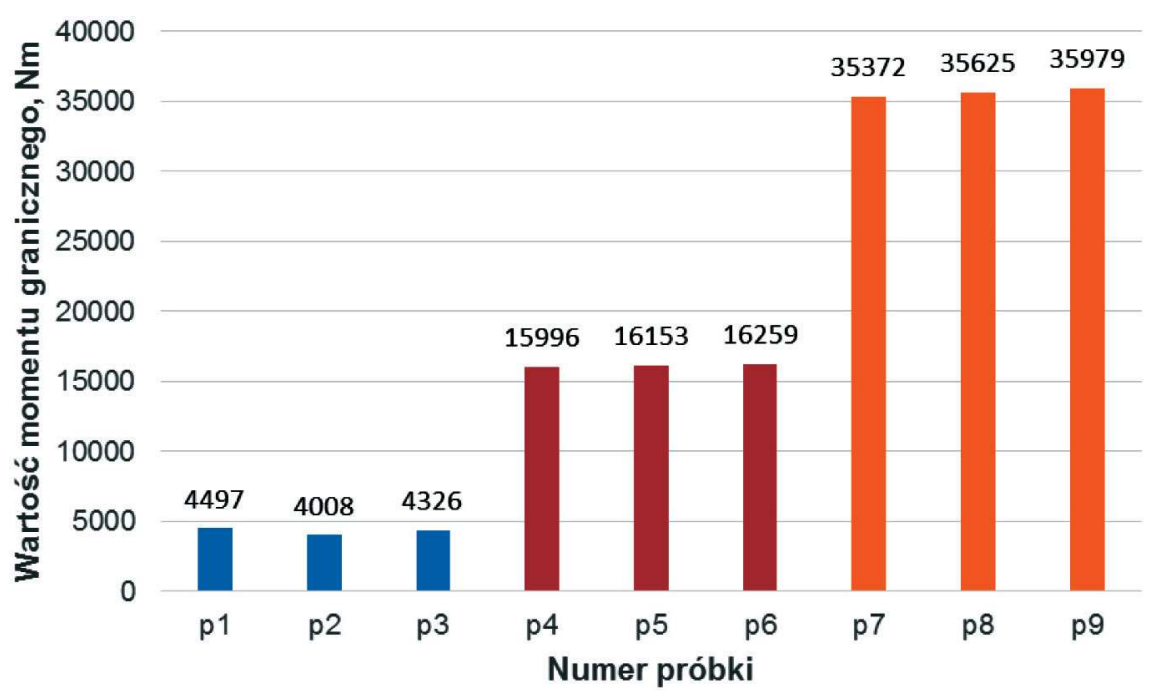

Rys. 7. Wartości momentu granicznego dla badanych kołków, gdzie: p1-p3 kotki o średnicy $5 \mathrm{~mm}$, p4-p6 kotki o średnicy $10 \mathrm{~mm}$, p7-p9 kotki o średnicy $15 \mathrm{~mm}$

Dla kołków o średnicy 5 mm największa wartość momentu obrotowego $M_{g r \max }$, przy której nastąpiło rozłączenie sprzęgła, wynosiła $4497 \mathrm{Nm}$. Z kolei najmniejsza wartość momentu $M_{g r \min }$ wynosiła $4008 \mathrm{Nm}$. Wobec powyższego współczynnik $\gamma_{5}$, określający dokładność ograniczenia obciążenia dla rozważanego sprzęgła oblicza się ze wzoru [1].

$$
\gamma_{5}=\frac{M_{g r \max }}{M_{g r \min }}=\frac{4497}{4008}=1,12
$$

Podobnie wyznaczono wartość współczynnika $\gamma_{5}$ dla pozostałych średnic kołków zabezpieczających. Obliczone wartości współczynnika $\gamma_{5}$ przedstawiono w tabeli 3.
Tabela 3

Wartości współczynnika $\gamma_{5}$ określającego dokładność ograniczenia momentu obciążenia sprzęgła

\begin{tabular}{|l|c|c|c|}
\hline Średnica kołka $\boldsymbol{d}[\mathrm{mm}]$ & 5 & 10 & 15 \\
\hline Wartość współczynnika $\boldsymbol{\gamma}_{\mathbf{5}}$ & 1,12 & 1,02 & 1,02 \\
\hline
\end{tabular}

Dla sprzęgieł ze ścinanymi kołkami według [1] wartość współczynnika dokładności wyłączenia sprzęgła powinna zawierać się w granicach od 1,1-1,4. Wobec powyższego na podstawie wyników badań można stwierdzić, że wszystkie kołki zabezpieczające zostały wykonane prawidłowo zarówno pod względem 
obróbki mechanicznej, jak i obróbki cieplnej, a kołki o średnicy 10 mm i 15 mm spełniają z naddatkiem kryterium według [1].

Na rysunku 8 przedstawiono porównanie obliczonych wartości momentu granicznego $M_{\text {gro }} \mathrm{z}$ uśrednionymi wartościami momentu granicznego $M_{g r}$ (według tab. 2) uzyskanymi z badań.

Jak można zauważyć, wartości przeliczonego momentu granicznego $M_{g r}$ uzyskane na podstawie badań doświadczalnych (ścięcia kołków) są większe od war- tości momentu granicznego $M_{\text {gro }}$ uzyskanych z obliczeń. Dla kołków o średnicy $5 \mathrm{~mm}$ różnica wyniosła

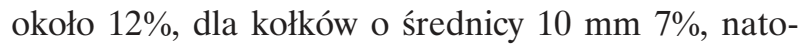
miast dla kołków 15 mm - 5\%. Różnica w wartościach momentu granicznego pomiędzy wynikami uzyskanymi z obliczeń a wynikami z badań doświadczalnych może wynikać np. z przyjętej do obliczeń wartości naprężenia dopuszczalnego na ścinanie $k_{t}$ oraz współczynnika proporcjonalności $k_{o}$ w obliczeniach wytrzymałościowych.

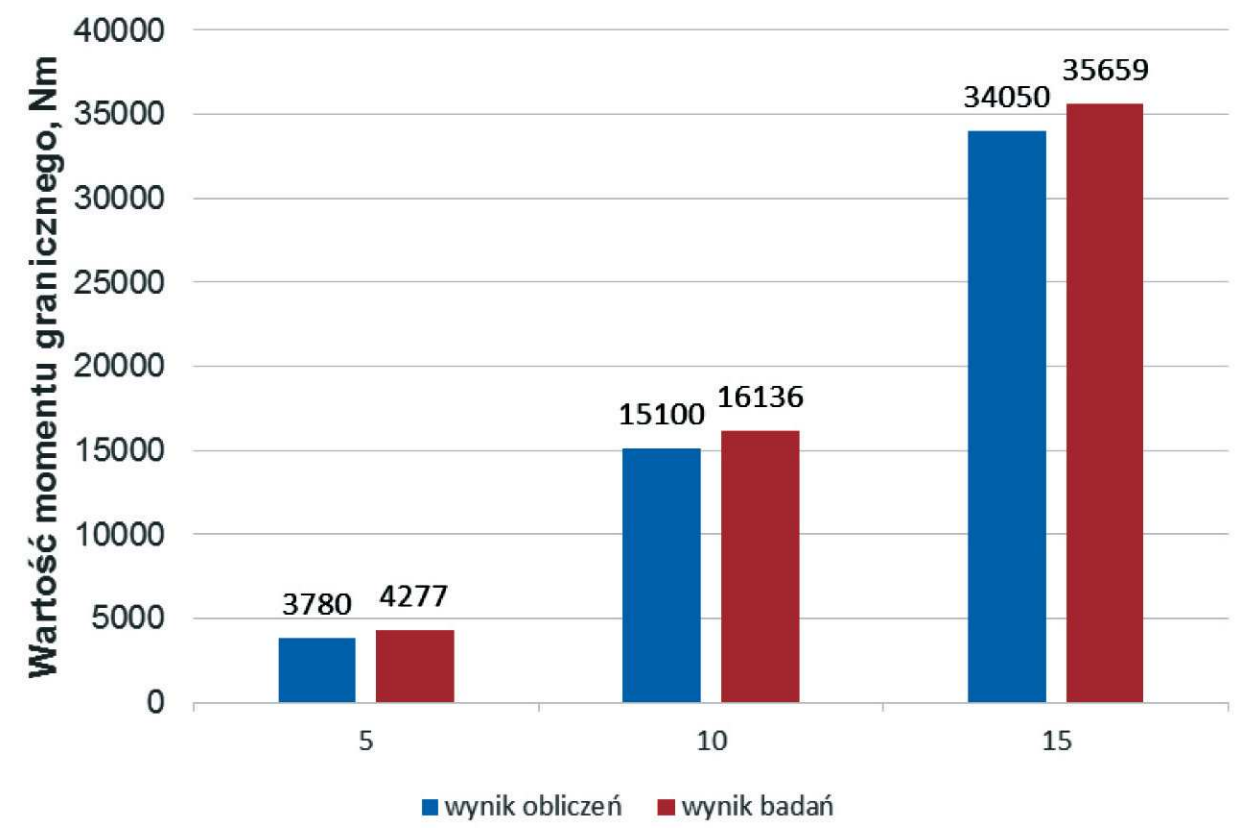

Rys. 8. Porównanie wartości obliczonego momentu granicznego z wartościa średnia dla badanych próbek

\section{PODSUMOWANIE}

Najprostszym zabezpieczeniem elementów układu napędowego przed przeciążeniem są sprzęgła bezpieczeństwa z łącznikami ulegającymi zniszczeniu. W przypadku sprzęgła Raptor-SK łączniki mają kształt cylindrycznego kołka z dwoma powierzchniami montażowymi.

Wykonane w pracy obliczenia średnic kołków ścinanych dla określonych wartości momentów granicznych oraz przeprowadzone badania doświadczalne dla ich trzech średnic wykazały, że:

- występuje różnica w wartości momentu granicznego $M_{g r}$ pomiędzy wartościami obliczonymi $\left(M_{g r o}\right)$ a uzyskanymi z badań $\left(M_{g r}\right)$ (rys. 8),

- większe wartości momentu granicznego $M_{g r}$ występują dla wyników uzyskanych z badań doświadczalnych (rys. 8),
- na podstawie badań doświadczalnych dla każdej ze średnic kołków uzyskano zbliżone wartości momentu granicznego $M_{g r}$ (rys. 7); wskaźnik określający dokładność ograniczenia obciążenia $\gamma 5$ wyniósł maksymalnie 1,12 dla badanej średnicy $5 \mathrm{~mm}$ (tab. 3).

$\mathrm{Z}$ dokonanej w pracy analizy można stwierdzić, że dla obliczonych średnic kołków ścinanych po przeprowadzeniu badań doświadczalnych uzyskano większe wartości momentu granicznego, niż założono w obliczeniach teoretycznych. Różnica jest tym większa, im mniejsza jest średnica kołka zabezpieczającego. Ostatecznie spowoduje to, że zadziałanie zabezpieczenia sprzęgła wystąpi przy większej wartości momentu granicznego niż spodziewany, wynikający z obliczeń.

Podsumowując całość analiz przeprowadzonych w pracy, można stwierdzić, że szczególnie w przypadku zastosowania tych sprzęgieł (z kołkami zabezpieczającymi) w maszynach majacych duże znaczenie 
eksploatacyjne należy rozważyć dobór średnicy kołków zabezpieczających oparty nie tylko na obliczeniach teoretycznych, a również przeprowadzić badania sprawdzające.

\section{Literatura}

[1] Dietrich M. (red.): Podstawy konstrukcji maszyn, t. 3, Wydawnictwa Naukowo-Techniczne, Warszawa 1999.

[2] https://voith.com/corp-en/torque-limiting-couplings.html [20.05.2018].

[3] www.fena.pl [20.05.2018].

[4] https:/www.baldor.com/brands/baldordodge/products/couplingsclutches-brakes/elastomeric-couplings/raptor [20.05.2018].

[5] Skoć A., Spałek J., Markusik S.: Podstawy konstrukcji maszyn, t. 2, Wydawnictwa Naukowo-Techniczne, Warszawa 2008 dr hab. inż. KRZYSZTOF FILIPOWICZ

dr inż. MARIUSZ KUCZAJ

Katedra Mechanizacji i Robotyzacji Górnictwa

Wydziat Górnictwa i Geologii

Politechnika Ślaska

ul. Akademicka 2a, 44-100 Gliwice

\{krzysztof.filipowicz, mariusz.kuczaj\}@polsl.pl

mgr inż. PAWEŁ GRUSZKA

Fabryka Elementów Napędowych FENA Sp. z o.o.

ul. E. Imieli 47, 41-605 Świętochłowice

dz.techniczny@fena.pl 